38. Paliy A. P., Sumakova N. V., Mashkey A. M., Petrov R. V., Paliy A. P., Ishchenko K. V. Contamination of animalkeeping premises with eggs of parasitic worms. Biosystems Diversity. 2018. Vol. 26, No. 4. P 327-333.

39. Нагорна Л. В., Проскуріна І. В. Особливості інсектицидних обробок у скотарстві. Вет. медицина : міжвід. темат. наук. зб. 2018. Вип. 104. С. 424-427.

\title{
APPLICATION OF INSECTICIDES IN INDUSTRIAL ANIMAL BREEDING
}

Paliy A. P., Mashkey A. M., Sumakova N. V., Gontar V. V.

National Scientific Center "Institute of Experimental and Clinical Veterinary Medicine", Kharkiv, Ukraine

Paliy A. $P$.

Petro Vasylenko Kharkiv National Technical University of Agriculture, Kharkiv, Ukraine

Entomoses of farm animals are widespread in the territory of Ukraine and cause significant economic losses to animal husbandry. It is established that the sick animals have reduced milk, meat and wool productivity, breeding qualities; weakened young animals, which are easily exposed to various diseases of infectious and noninfectious etiology, are born. Among all modern methods and means for artificial reduction of the number of insects, the most effective is the chemical method. To protect animals from midges the most cost-effective is the spraying of animals with insecticides and repellents. The analysis of the presented literature data allows us to say that sufficiently large range of effective preparations of both domestic and foreign production is presented on the market of disinsection agents. However, it has been reported that resistance to insects has formed for most of them, some of the products are highly toxic to warm-blooded animals, and also they are quite expensive and their use is economically unjustified. Great scientific and practical importance has the development of modern methods of combating the causative agents of farm animal entomoses based on strict regulations for treatment-andprophylactic means, which make it possible to reduce the number of parasites to an economically intangible level, prevent environmental pollution by pesticides, and obtain safe animal products of high sanitary quality. The insecticide market has a fairly large range of efficient products, both domestic and foreign, but most of them do not meet modern challenges and advanced livestock technologies. At the present stage of the disinfectology development, the search for new compositions of chemical compounds for disinsection in animal husbandry to combat harmful insects is promising

Keywords: insects, insecticide, repellent, active ingredient, synthetic pyrethroids, farm animals

\section{ПОШИРЕННЯ ЕЙМЕРІОЗУ ГОЛУБІВ В УМОВАХ ІНДИВІДУАЛЬНИХ ГОСПОДАРСТВ СХІДНОГО РЕГІОНУ УКРАЇНИ}

\author{
Люлін П. В. \\ Харківська державна зооветеринарна академія, \\ Харків, Україна, e-mail: liulinpetr@gmail.com
}

У статmі наведені результати дослідження епізоотичної ситуації - поширення еймеріозу голубів в умовах індивідуальних господарств сходу України (ЕI - 52,3 \%). Встановлений видовий склад збудників еймеріозу голубів Eimeria labbeana (71,0 - 81,5 \%), Eimeria columbarum (14,5 - 26,5\%), Eimeria columbae (2,5-4,0\%)

Ключові слова: голуби, еймерії, екстенсивність, інтенсивність, інвазія

Еймеріоз голубів - протозойна хвороба, збудником якої є моноксенні, внутрішньоклітинні, епітеліотропні паразити з підцарства Protozoa, типу Apicomplexa, классу Sporozoa, ряду Coccidiida, родини Eimeriidae, роду Eimeria, видів Eimeria columbae (Mitra and Das Gupta, 1937), Eimeria columbarum (Nieschulz, 1935), Eimeria labbeana (Labbe, 1896, Pinto, 1928) [1, 2].

Хвороба характеризується розладами травлення, проявляється діареєю, часто 3 прожилками крові, спрагою, супроводжується втратою крові, розвитком анемії, інколи нервовими явищами, відставанням у рості та розвитку і навіть загибеллю молодняка від 5-30 до 35-50 \%, чим і завдає значних економічних збитків [3-7].

Хворі птиці втрачають здатність до польоту, пригнічені, апетит відсутній, мають настовбурчене пір'я, втягують голову, тонус крил ослаблений. 
У зв'язку з вищевикладеним, дослідження епізоотичної ситуації щодо поширення еймеріозу голубів у регіонах України, визначення видового складу збудників $є$ важливим для розробки ефективних заходів боротьби і профрілактики. Тому метою роботи було з'ясувати епізоотичну ситуацію щодо поширення еймеріозу голубів в умовах індивідуальних господарств східного регіону України та визначити видову належність збудників еймеріозу.

Матеріали і методи дослідження. Робота виконувалась протягом 2016-2019 років на базі індивідуальних господарств із утримання голубів в Харківській, Сумській, Донецькій і Полтавській областях. Матеріалом для дослідження слугували фрекалії від голубів загальною кількістю 926 проб. Матеріал (фекалії) відбирали методом випадкової вибірки з підлоги та індивідуально під час дефекації. Відібраний матеріал досліджували в лабораторії кафедри паразитології Харківської державної зооветеринарної академії стандартизованим методом Фюлеборна [6, 8]. Мікроскопічні дослідження проводили за малого збільшення мікроскопу $(8 \times 10)$ з подальшим визначенням середніх показників екстенсивності інвазії (EI, \%) та інтенсивності інвазії (II, кількість ооцист в 1 г фекалій). Видову належність збудників еймеріозу визначали за результатами власних досліджень морфології ооцист (форми, кольору, строків споруляції) порівнюючи їх з даними визначальних таблиць L. P. Pellerdy (1974) [2].

Результати досліджень. За результатами спеціальних копроскопічних досліджень різновікових груп голубів індивідуальних господарств східного регіону України інвазованість на еймеріоз в середньому склала 52,3 \% (табл.)

Таблиця - Поширення еймеріозу голубів на сході України

\begin{tabular}{|l|c|c|c|c|}
\hline \multicolumn{1}{|c|}{ Область } & Досліджено, гол. & Інвазовано, гол. & El, \% & II, ооцист в 1 г фекалій \\
\hline Харківська & 217 & 109 & 50,2 & $274,5 \pm 12,5$ \\
\hline Сумська & 223 & 147 & 65,9 & $308,6 \pm 16,8$ \\
\hline Донецька & 249 & 117 & 46,9 & $198,3 \pm 13,6$ \\
\hline Полтавська & 237 & 112 & 47,2 & $243,5 \pm 14,5$ \\
\hline Всього & 926 & 485 & 52,3 & $256,2 \pm 40,6$ \\
\hline
\end{tabular}

Як видно з таблиці, інвазованість голубів східного регіону України висока. Найменша екстенсивність інвазії виявлялась у голубів індивідуальних господарств Донецької та Полтавської областей - відповідно 46,9 та 47,2 \%, в Харківській області - 50,2 \% і найвища в Сумській області - 65,9 \%. При цьому інтенсивність інвазії була різноманітна: слабка (1-10 ооцист в 1 г фекалій) реєструвалась у 43-64 \%, середня (11-100 ооцист в 1 г фекелій) - у 26-45 \% та сильна (> 100 ооцист) в 1 г фрекалій - у 10-12 \% від кількості інвазованих голубів.

Видовий склад збудників еймеріозу голубів представлений трьома видами еймерій Eimeria columbae, Eimeria columbarum, Eimeria labbeana. Із них у загальній кількості ооцист найбільш поширеним видом виявилась Eimeria labbeana (71,0-81,5 \%), Eimeria columbarum (14,5-26,5 \%), Eimeria columbae (2,5-4,0 \%). Таким чином, основними видами, що спричиняють еймеріоз голубів сходу України є Eimeria labbeana та Eimeria columbarum, і значно меншу частку в патології еймеріозу складає вид Eimeria columbae.

Висновки. 1. Еймеріоз голубів в умовах індивідуальних господарств сходу України широко поширена інвазія (EI - 52,3\%).

2. Клінічно еймеріоз голубів перебігав із слабким ступенем інвазії у 43-64 \%, середнім - у 26-45 \% та сильним - у 10-12 \% поголів'я голубів.

3. Основними видами еймеріозу голубів сходу України є Eimeria labbeana $(71,0-81,5 \%)$ та Eimeria columbarum (14,5-26,5 \%), a Eimeria columbae мав незначне поширення $(2,5-4,0 \%)$.

\section{Список ліmepamyрu}

1. Krautwald-Junghanns M. E. Zebisch R., Schmidt V. Relevance and treatment of coccidiosis in domestic pigeons (Columba livia forma domestica) with particular emphasis on toltrazuril. Journal of Avian Medicine and Surgery. 2009. Vol. 23, No. 1. P. 1-5.

2. Pellérdy L. P. Coccidia and coccidiosis. Berlin : Verlag Paul Parey and Akademiai Kiady, 1974. 959 p.

3. Romaniuk K. Robaczyce gołębi. Magazyn Weterynaryjny. 2000. No. 9. S. 48.

4. Stenzel T., Koncicki A. 2007. Occurrence of parasitic invasions in domestic pigeons (Columba livia domestica) in the Northern Poland. Polish Journal of Veterinary. 2007. No. 10. P. 275-278. 
5. Szeleszczuk P. Praktyczne uwagi na temat terapii i profilaktyki chorób gołębi domowych. Magazyn Weterynaryjny. 1995. No. 4. P. 25-30.

6. Бакулин В. А. Болезни птиц. Санкт-Петербург, 2006. С. 364-374.

7. Бейер Т. В. Протисты : руководство по зоологии. Часть 2. Класс Coccidea Leuckart, 1879 - Кокцидии. — СанктПетербург : Наука, 2007. С. 216-229.

8. Котельников Г. А. Гельминтологические исследования окружающей среды. Москва : Россагропромиздат, 1991. -144 c.

\section{SPREAD OF PIGEON EIMERIOSIS IN THE CONDITIONS OF INDIVIDUAL FARMS OF THE EASTERN REGION OF UKRAINE}

\section{Lyulin P. V.}

Kharkiv State Zooveterinary Academy, Kharkiv, Ukraine

Compliance with veterinary sanitary norms and rules for keeping pigeons does not completely solve the problem of eimeriosis due to the high reproductive ability of the parasite and the long (about a year) preservation of oocysts in the external environment. The aim of the work was to study the epizootic situation regarding the spread of pigeon eimeriosis in individual farms in the eastern region of Ukraine and to determine the species composition of pathogens. Feces of pigeons from individual farms of the eastern region of Ukraine (Kharkiv, Donetsk, Sumy and Poltava regions) served as material for research. 926 samples of pigeon feces were investigated by flotation methods. The species belonging of the causative agents of eimeriosis was determined by the results of own studies of oocyst morphologies and by data from L. P. Pellerdy tables (1974). As a result of studies, it was found that pigeon eimeriosis is widespread in individual farms in the eastern region of Ukraine (prevalence - 52.3\%). The smallest eimeriosis invasion was detected in pigeons in Donetsk and Poltava regions, $46.9 \%$ and $47.2 \%$ respectively, in Kharkov region - 50.2\%, and the largest in Sumy region - $65.9 \%$. At the same time, a weak degree of invasion (1-10 oocysts in $1 \mathrm{~g}$ of feces) was recorded in 43-64\%, medium (11-100 oocysts in $1 \mathrm{~g}$ of feces) $-26-45 \%$ and strong (> 100 oocysts in $1 \mathrm{~g}$ feces) $-10-12 \%$ of the number of invaded birds. In the eastern region of Ukraine, three species of Eimeria that cause eimeriosis of pigeons (Eimeria columbae, Eimeria columbarum, Eimeria labbeana) were identified, the ratio of which in the total number of oocysts ranged: Eimeria labbeana - 71.0-81.5\%, Eimeria columbarum - 14.5-26.5\%, Eimeria columbae - 2.5-4.0\%

Keywords: pigeons, Eimeria, extensiveness, invasion intensity 